\title{
Mercury (Hg) contamination in Manado Bay, North Sulawesi, Indonesia
}

\section{Kontaminasi merkuri (Hg) di Teluk Manado, Sulawesi Utara, Indonesia}

\author{
Stephen R. Ronoko, ${ }^{1}$ Denny B.A. Karwur, ${ }^{2}$ and Markus T. Lasut ${ }^{1,3 *}$ \\ ${ }^{1}$ Program Studi Ilmu Perairan, Program Pascasarjana, Universitas Sam Ratulangi. Jln. Kampus Unsrat Kleak, \\ Manado 95115, Sulawesi Utara, Indonesia \\ ${ }^{2}$ Fakultas Hukum, Universitas Sam Ratulangi, Manado \\ ${ }^{2}$ Fakultas Perikanan dan Ilmu Kelautan, Universitas Sam Ratulangi \\ *E-mail:lasut.markus@unsrat.ac.id
}

\begin{abstract}
Artisanal gold minings, which are situated in the highlands of the northern part of Sulawesi Island, use mercury ( $\mathrm{Hg}$ ) to extract gold and discharge theirs tailings into rivers; one of the rivers (Bailang River) is connected to Manado Bay. This could cause Hg contamination into the bay. This study aimed to assess the contamination of $\mathrm{Hg}$ in the aquatic ecosystem of the bay. For the assessment, the bay was divided into 2 parts, namely the North and the South, and the contamination was assessed by measuring the total $\mathrm{Hg}$ concentration in sediments and fishes. Determination of $\mathrm{Hg}$ concentration refers to the Indonesian National Standard (SNI) 012896-1992 and Guidance of Balai Riset dan Standarisasi Industri Manado. The results showed that the range of $\mathrm{Hg}$ concentrations in fish varied by species; in the northern part of the bay: Holocentridae (0.1144-0.1151 ppm), Siganidae (0.0020-0.0034 ppm), Apogonidae (0.0461-0.050 ppm), and Nemipterus (0.0142-0.0144 ppm ). While in the southern part of the bay: Holocentridae (0.1090-0.1104 ppm), Siganidae (0.160-0.164 ppm), Apogonidae (0.1280-0.1291 ppm), Nemipterus (0.0522-0.0530 ppm), and Priacanthus sp. (0.0194-0.0210 ppm). The average concentration of $\mathrm{Hg}$ in sediments of the bay around river mouths varied based on location, i.e. Bailang River was $0.0502 \mathrm{ppm}$, Sario River was $0.0270 \mathrm{ppm}$, Bahu River was $0.0615 \mathrm{ppm}$, and Malalayang River was $0.0143 \mathrm{ppm}$.
\end{abstract}

Keywords: mercury; Hg; fish; sediment; Manado Bay.

Abstrak: Pertambangan emas rakyat menggunakan merkuri (Hg), yang berada di daerah dataran tinggi bagian Utara Pulau Sulawesi, membuang limbah tailing ke sungai menuju ke laut; satu dari sungai tersebut (Sungai Bailang) bermuara ke Teluk Manado. Hal ini dapat menyebabkan kontaminasi $\mathrm{Hg}$ ke lingkungan perairan teluk. Penelitian ini bertujuan untuk menilai kontaminasi $\mathrm{Hg}$ di ekosistem perairan teluk tersebut. Untuk penilaian, perairan teluk dibagi 2 bagian, yaitu bagian Utara dan Selatan, dan kontaminasi dinilai dengan cara mengukur konsentrasi $\mathrm{Hg}$ total pada sedimen dan ikan. Penentuan konsentrasi Hg mengacu Standar Nasional Indonesia (SNI) 01-2896-1992 dan Panduan Balai Riset dan Standarisasi Industri Manado. Hasil penelitian menunjukkan, bahwa kisaran konsentrasi $\mathrm{Hg}$ dalam ikan bervariasi berdasarkan jenis; di bagian Utara teluk: Holocentridae $(0,1144-0,1151 \mathrm{ppm})$, Siganidae (0,0020-0,0034 ppm), Apogonidae (0,0461-0,050 ppm), dan Nemipterus $(0,0142-0,0144 \mathrm{ppm})$. Sedangkan di perairan bagian Selatan teluk: Holocentridae (0,1090-0,1104 ppm), Siganidae (0,160-0,164 ppm), Apogonidae (0,1280-0,1291 ppm), Nemipterus (0,0522-0,0530 ppm), dan Priacanthus sp. (0,0194-0,0210 ppm). Konsentrasi rata-rata $\mathrm{Hg}$ di sedimen perairan teluk sekitar muara Sungai Bailang sebesar 0,0502 ppm, muara Sungai Sario sebesar 0,0270 ppm, muara Sungai Bahu sebesar 0,0615 ppm, dan muara Sungai Malalayang sebesar 0,0143 ppm.

Kata-kata kunci: merkuri; Hg; ikan; sedimen; Teluk Manado.

\section{PENDAHULUAN}

Kota Manado terletak di ujung Pulau Sulawesi dan merupakan kota terbesar di belahan Utara pulau tersebut; kota ini sebagai ibukota Provinsi Sulawesi Utara. Kota ini dilintasi oleh lima sungai besar, yaitu Sungai Tondano, Sungai Bailang, Sungai Tikala, Sungai Sario, dan Sungai Malalayang, yang bermuara ke Teluk Manado. Perairan Teluk Manado merupakan perairan yang memiliki tingkat aktivitas manusia yang cukup tinggi, baik secara langsung maupun tidak, misalnya penangkapan ikan, transportasi, dan pariwisata, serta aktivitas di daerah perkotaan (Lasut et al., 2005a). Kondisi perairan di teluk ini berpotensi terkontaminasi dengan bahan-bahan pencemar, karena buangan limbah dari kegiatan di perkotaan yang masuk ke 
perairan tersebut dalam status tercemar (Lasut et al., 2005a) dan di tambah dengan aktivitas pertambangan rakyat di sekitar daerah Kota Manado yang membuang tailing dan masuk di Teluk Manado melalui aliran sungai yang bermuara di Teluk Manado.

Limbah cair masuk ke daerah pesisir dan laut, melalui sungai (Bereswill et al., 2012; KockSculmeyer et al., 2012), membawa semua komponen (organik dan non organik, dapat terurai dan tidak dapat terurai, sangat berbahaya dan tidak berbahaya (Ouyang, 2012). Merkuri (Hg) yang terdapat dalam limbah cair sangat berbahaya terhadap ekosistem perairan.

Pencemaran logam berat merupakan permasalahan yang sangat serius untuk ditangani, karena merugikan lingkungan dan ekosistem secara umum. Di antara berbagai macam logam berat, merkuri digolongkan sebagai pencemar paling berbahaya. Adanya kemampuan mengakumulasi merkuri di dalam tubuh biota laut dapat membahayakan kehidupan biota yang bersangkutan maupun biota lainnya, misalnya melalui rantai makanan atau food chain (Budiono, 2003). Hubungan antara konsumsi makanan laut yang terpolusi dan kesehatan manusia saat ini kian menjadi-jadi. Makanan laut, seperti ikan, dapat terkontaminasi logam dan logam berat di lingkungan perairan (Lasut et al., 2010; Komalig et al., 2010). Sehubungan dengan hal tersebut, maka penelitian ini, yang bertujuan untuk menilai status pencemaran merkuri $(\mathrm{Hg})$ di ekosistem perairan Teluk Manado, dilaksanakan.

\section{MATERIAL DAN METODA}

\section{Prosedur Penelitian}

Lokasi pengambilan sampel di lakukan di sekitar perairan Teluk Manado. Variabel yang digunakan adalah kandungan merkuri total $(\mathrm{THg})$ dalam sedimen perairan pantai dan ikan. Lokasi pengambilan sampel ikan, yaitu di bagian Utara dan Selatan Teluk Manado; sedangkan, sedimen di ambil dari sekitar muara Sungai Bailang, muara S. Sario, muara S. Bahu, dan muara S. Malalayang.

Empat daerah di pinggiran perairan Teluk Manado dipilih sebagai stasiun pengamatan (ST) untuk pengambilan sampel sedimen, masing-masing terdiri dari 4 titik pengambilan sampel. Posisi keempat ST tersebut, secara kasar, ditentukan menggunakan perangkat GPS (Gambar 1). Pengambilan contoh uji sedimen pantai dilakukan menurut Lasut et al. (2010). Sedimen (di kedalaman

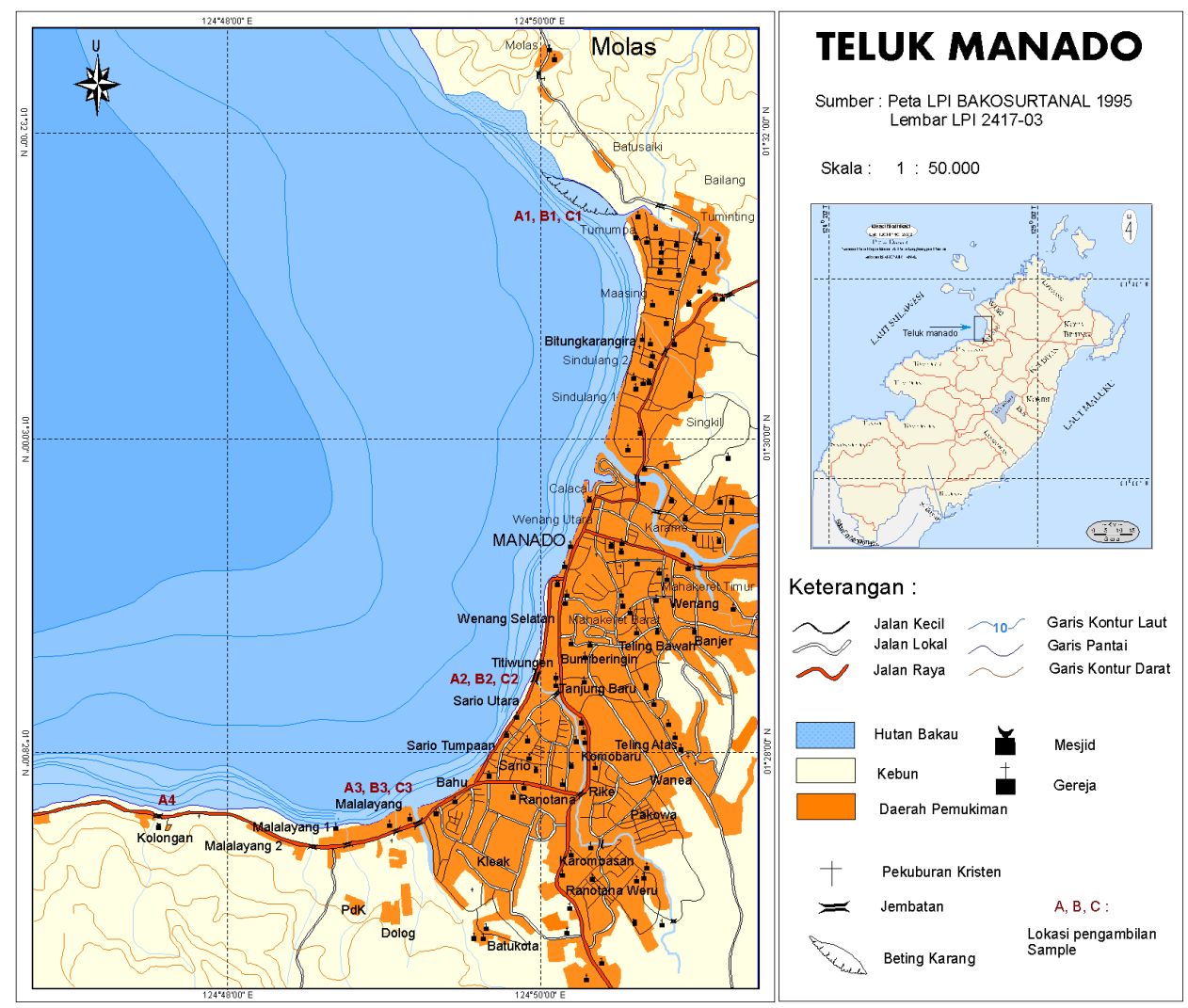

Gambar 1. Lokasi Pengambilan Sampel. A1-A3: pengamatan pada sedimen; B1-B3: pengamatan pada ikan 
5-10 cm; ukuran partikel $<2 \mathrm{~mm}$; bersih dari kotoran) diambil pada saat air surut dengan menggunakan sediment core yang terbuat dari pipa polyvinyl chloride (PVC) (diameter 2,5 inch). Lima sampel (contoh uji) diambil dan dicampur menggunakan metoda quartering untuk mendapatkan satu komposit contoh uji sedimen masing-masing ST, contoh uji (kira-kira sebanyak 500 gram) ditempatkan dalam kantong plastik polyethylene. Selama di lapangan dan transportasi ke laboratorium, contoh uji di tempatkan di dalam kotak pendingin bersama dengan gel pendingin untuk menjaga kondisi suhu yang rendah. Hal ini dilakukan untuk mencegah proses pelapukan $\mathrm{Hg}$ oleh organisme renik (mikroorganisme). $\mathrm{Di}$ laboratorium, contoh uji dianalisis untuk mengukur kandungan merkuri total (THg).

Empat jenis ikan, masing-masing berjumlah 3 individu, digunakan sebagai contoh uji. Contoh uji ikan diperoleh dari tangkapan yang menggunakan panah melalui nelayan di perairan Teluk Manado. Jenis ikan ini ditentukan kemudian dengan cara mengidentifikasinya menggunakan buku penuntun identifikasi. Di laboratorium, contoh uji dianalisis untuk mengukur kandungan merkuri total $(\mathrm{THg})$. Penentuan kandungan merkuri $\mathrm{Hg}$ mengacu Standar Nasional Indonesia (SNI) 01-2896-1992 dan Panduan Balai Riset dan Standarisasi Industri Manado (Anonymous, 2011).

\section{Analisis Data}

Analisis sampel secara deskriptif dengan membandingkan dari beberapa lokasi penelitian dan membandingkan dengan standar baku untuk ikan membandingkan dengan World Health Organization (WHO, 1990) dan sedimen membandingkan dengan Dutch Quality Standards for Metals in Sediment (IADC/CEDA, 1997).

\section{HASIL DAN PEMBAHASAN}

\section{Konsentrasi Merkuri (Hg) Dalam Ikan}

Hasil analisis konsentrasi merkuri $(\mathrm{Hg})$ dalam 4 jenis ikan demersal yang berada di bagian Utara

Tabel 1. Konsentrasi Merkuri (Hg) dalam ikan di Perairan Sebelah Utara dan Selatan Teluk Manado

\begin{tabular}{|c|c|c|c|c|}
\hline Lokasi & Jenis Ikan & Ulangan & Konsentrasi Merkuri (ppm) & $\begin{array}{l}\text { Nilai Ambang } \\
\text { (threshold) WHO }\end{array}$ \\
\hline \multirow[t]{2}{*}{ Bagian Utara } & & 1 & 0,1151 & \\
\hline & Holocentridae & 2 & 0,1150 & \\
\hline \multirow[t]{10}{*}{ Teluk Manado } & & 3 & 0,1144 & \\
\hline & & 1 & 0,0034 & \\
\hline & Siganidae & 2 & 0,0024 & \\
\hline & & 3 & 0,0020 & \\
\hline & & 1 & 0,0461 & \\
\hline & Apogonidae & 2 & 0,0490 & \\
\hline & & 3 & 0,050 & \\
\hline & & 1 & 0,0144 & \\
\hline & Nemipterus & 2 & $\mathrm{Ttd}$ & \\
\hline & & 3 & 0,0142 & \\
\hline \multirow[t]{2}{*}{ Bagian Selatan } & & 1 & 0,1103 & \\
\hline & Holocentridae & 2 & 0,1090 & 0,5 \\
\hline \multirow[t]{13}{*}{ Teluk Manado } & & 3 & 0,1104 & \\
\hline & & 1 & 0,0160 & \\
\hline & Siganidae & 2 & 0,0164 & \\
\hline & & 3 & 0,0161 & \\
\hline & & 1 & 0,1291 & \\
\hline & Apogonidae & 2 & Ttd & \\
\hline & & 3 & 0,1280 & \\
\hline & & 1 & 0,0530 & \\
\hline & Nemipterus & 2 & Ttd & \\
\hline & & 3 & 0,0522 & \\
\hline & & 1 & 0,0194 & \\
\hline & Priacanthus sp. & 2 & Ttd & \\
\hline & & 3 & 0,0210 & \\
\hline
\end{tabular}


Teluk Manado, tepatnya di perairan sekitar muara S. Bailang, yaitu Holocentridae dengan konsentrasi berkisar 0,1144 - 0,1151 ppm, Siganidae dengan konsentrasi berkisar 0,0020 - 0,0034 ppm, Apogonidae dengan konsentrasi berkisar 0,0461 $0,050 \mathrm{ppm}$, dan Nemipterus dengan konsentrasi berkisar 0,0142 - 0,0144 ppm. Sedangkan konsentrasi merkuri $(\mathrm{Hg})$ yang diambil dari 5 jenis ikan di bagian Selatan Teluk Manado, yaitu Holocentridae dengan kisaran konsentrasi 0,1090 - 0,1104 ppm, Siganidae dengan kisaran konsentrasi 0,160 - 0,164 ppm, Apogonidae dengan kisaran konsentrasi 0,1280 - 0,1291 ppm, Nemipterus dengan kisaran konsentrasi 0,0522 - 0,0530 ppm dan Priacanthus sp. dengan kisaran konsentrasi 0,0194 - 0,0210 ppm (Tabel 1).

Adanyanya kandungan merkuri dalam tubuh ikan di duga berasal dari berbagai aktivitas, baik aktivitas rumah tangga, industri maupun pertambangan; namun, dapat juga berasal dari alam/perairan itu sendiri. Kontaminasi merkuri dalam jaringan ikan dapat terjadi melalui kulit, saluran pernafasan, dan saluran pencernaan. Logam berat merkuri yang masuk ke dalam tubuh ikan akan memberikan dampak buruk terhadap kesehatan manusia, terutama saat manusia mengkonsumsi ikan tersebut (Triyani, 2009).

Konsentrasi rata-rata merkuri dalam daging ikan yang berasal dari perairan bagian Utara dan Selatan Teluk Manado ditampilkan pada Gambar 2.
Konsentrasi rata-rata merkuri dalam tubuh ikan jenis Holocentridae, yang di ambil dari bagian Utara Teluk Manado, lebih tinggi jika dibandingkan dengan konsentrasi rata-rata jenis ikan yang diambil dari bagian Selatan Teluk Manado, sedangkan jenis ikan Siganidae, Apogonidae, dan Nemipterus, yang diambil di bagian Selatan Teluk Manado, memiliki konsentrasi rata-rata merkuri lebih tinggi jika dibandingkan dengan konsentrasi rata-rata merkuri di bagian Utara Teluk Manado. Nampak, akumulasi merkuri pada ikan karnivora melalui rantai makanan dapat terjadi di lingkungan perairan dari kelompok organisme produsen ke kelompok konsumen tingkat yang lebih tinggi. Bioakumulasi $\mathrm{Hg}$ pada ikan merupakan proses yang rumit dan belum dipahami sepenuhnya (Lasut, 2009).

Konsentrasi rata-rata merkuri dalam ikan di perairan bagian Utara dan Selatan Teluk Manado berada di bawah konsentrasi yang direkomendasikan oleh World Health Organization (WHO), yaitu nilai ambang (threshold) yang aman untuk kandungan merkuri pada tubuh ikan konsumsi sebesar 0,5 ppm. Meskipun demikian, kandungan merkuri dalam tubuh ikan tersebut telah terdeteksi keberadaannya dan mengindikasikan adanya kontaminan perairan tempat habitat ikan tersebut di mana bahan pencemar dapat masuk ke dalam tubuh ikan melalui makanan dan absorbsi ion dari permukaan tubuh.

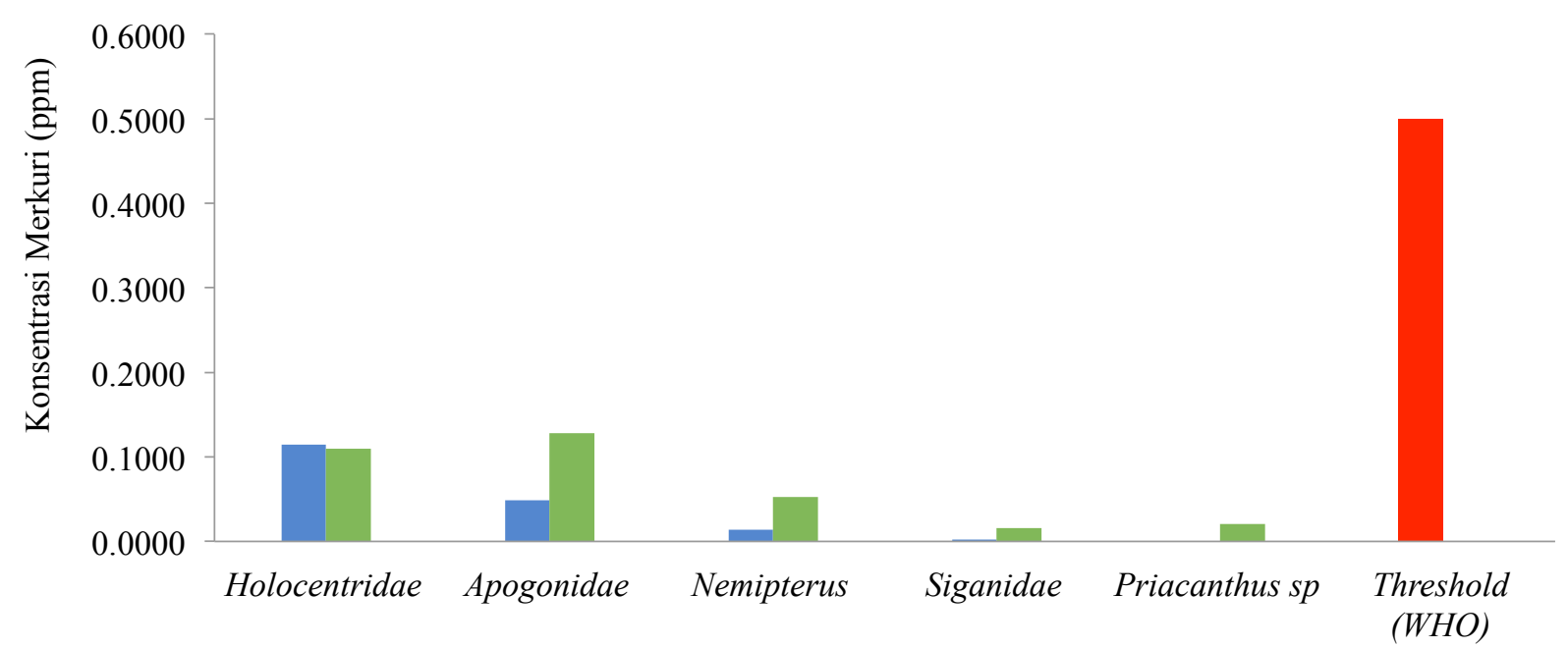

Jenis Ikan

Gambar 2. Konsentrasi Rata-Rata Merkuri (Hg) Dalam Daging Ikan yang Ditangkap di Perairan Sebelah Utara dan Selatan Teluk Manado 


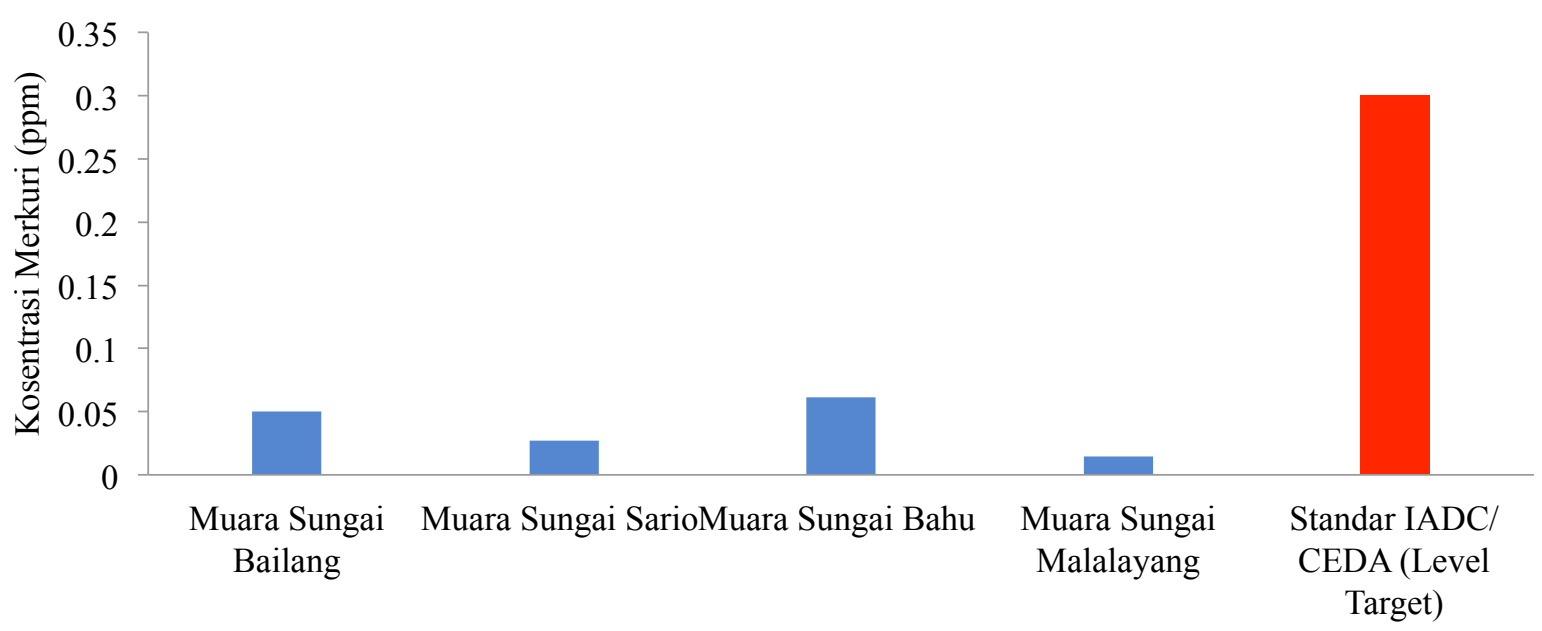

Lokasi Pengambilan Sampel dan Standar Baku Mutu

Gambar 3. Konsentrasi Rata-rata Merkuri (Hg) dalam Sedimen di Teluk Manado

Menurut Heath (1987) dalam Lasut (2009), sekitar $70 \%$ metil merkuri yang masuk lewat makanan akan diabsorpsi ke dalam jaringan tubuh ikan dan hanya $10 \%$ yang melalui penyerapan melalui insang. Menurut Mulyanto (1993) dalam Sudarmaji et al. (2006) menyatakan, bahwa $\mathrm{Hg}$ yang terakumulasi dalam tubuh organisme laut, misalnya ikan, akan diubah bentuk senyawanya menjadi metil merkuri yang umumnya tahan lama di dalam tubuh organisme tersebut dan secara lambat atau cepat akan dialihkan ke jenjang trofik yang lebih tinggi; kemudian, akhirnya dapat terakumulasi dalam tubuh manusia melalui pemanfaatan hewan laut sebagai bahan makanan. Akumulasi merkuri pada manusia dapat menyebabkan gangguan neurotoksik.

\section{Konsentrasi Merkuri (Hg) Dalam Sedimen}

Hasil analisis konsentrasi merkuri dalam sedimen pada 4 lokasi menunjukkan, bahwa konsentrasi rata-rata merkuri di sedimen sekitar muara S. Bailang sebesar 0,0502 ppm, muara S. Sario sebesar 0,0270 ppm, muara S. Bahu sebesar $0,0615 \mathrm{ppm}$, dan muara S. Malalayang sebesar 0,0143 ppm (Gambar 3). Mengacu pada Standar Baku Mutu International IADC/CEDA (IADC/CEDA, 1997), yaitu level target 0,3 ppm, maka konsentrasi merkuri di sedimen Teluk Manado berada di bawah standar baku IADC/CEDA (level target). Jika konsentrasi kontaminan yang ada pada sedimen memiliki nilai yang lebih kecil dari nilai level target, maka substansi yang ada pada sedimen tidak terlalu berbahaya bagi lingkungan. Konsen-trasi merkuri pada sedimen di Teluk Manado lebih kecil jika dibandingkan dengan konsentrasi merkuri di Teluk Buyat. Berdasarkan penelitian Lasut et al. (2005b), konsentrasi $\mathrm{THg}$ sampel sedimen yang diambil di bagian luar Teluk Buyat dekat daerah Kotabunan memiliki konsentrasi 1,689-3,510 ppm; di daerah bagian dalam Teluk Buyat memiliki konsentrasi 0,864 - 1,840 ppm; dan di lokasi di antara memiliki konsentrasi 0,292 ppm. Namun, dalam penelitian Lasut et al. (2010), ditemukan kisaran THg dengan konsentrasi 0,01 - 0,017 ppm.

Kandungan merkuri pada sedimen di Teluk Manado diperkirakan akan terus meningkat dan dapat berbahaya bagi organisme di perairan. Sanusi (2006) menyatakan, sifat kimia material padatan tersuspensi memiliki kemampuan mengadsorpsi logam berat terlarut dalam kolom air sehingga padatan tersebut akan mengakumulasi logam berat tersebut, selain material organik dalam sedimen.

Menurut Amin et al. (2009), 90\% logam berat yang terkontaminasi pada lingkungan perairan akan terendap di dalam sedimen. Chen et al. (2012) menyatakan, bahwa jumlah $\mathrm{Hg}$ yang terkandung dalam sedimen mencerminkan tingkat polusi bagi badan air. Hal ini menyebabkan konsentrasi bahan pencemar dalam sedimen meningkat. Logam berat yang masuk ke dalam lingkungan perairan akan mengalami pengendapan, pengenceran dan dispersi, kemudian diserap oleh organisme yang hidup di perairan tersebut.

\section{KESIMPULAN}

Konsentrasi merkuri total (THg) dalam beberapa jenis ikan, yang di ambil dari bagian Utara Teluk 
Manado, berkisar 0,0020 - 0,0144 ppm; sedangkan, yang diambil dari Selatan Teluk Manado berkisar 0,0194 - 0,1640 ppm. Konsentrasi rata-rata merkuri total (THg) pada sedimen di sekitar muara sungai di Teluk Manado berkisar antara 0,0143 (di muara S. Malalayang) dan 0,0615 ppm (di muara S. Bahu).

\section{REFERENSI}

AMIN, B., ISMAIL, A., ARSHAD, A., YAP, C.K. and KAMARUDIN, M.S. (2009) Anthropogenic impacts on heavy metal concentrations in the coastal sediments of Dumai, Indonesia. Environ. Monit. Assess. 148, 291-305.

ANONYMOUS (2011) Metode Ekstrasi dan Destruksi Sampel. Manado: Baristand.

BERESWILL, R., GOLLA, B., STRELOKE, M. and SCHULZ, R. (2012) Entry and toxicity of organic pesticides and copper in vineyard streams: erosion rills jeopardize the effeciency of riparian buffer strips. Ecosystem and Environment, 146, 81-92.

BUDIONO, A. (2003) Pengaruh Pencemaran Merkuri Terhadap Biota Air. Bogor: Institut Pertanian Bogor.

CHEN, C.W., CHEN, C.F. and DONG, C.D. (2012) Contamination and potential ecological of mercury in sediments of Kaohsiung river mouth, Taiwan. International Journal of Envitonmental Science and Development, 3(1), 66-71.

KOCK-SCHULMEYER, M., GINEBREDA, A., GONZALES, S., CORTINA, J.L., DE ALDA, M.L. and BARCELO, D. (2012) Analysis of the occurrence and risk assessment of polar pesticides in the $\mathrm{L}$ lobregat River basin (NE Spain). Chemosphere, 86, 8-16.

KOMALIG, R., LASUT, M.T. and TANGKUMAN, H.D. (2010) Kontaminasi merkuri dalam sedimen di Sungai Talawaan. Chemistry Progress, 3(2), 81-84.

LASUT, M.T., EDINGER, E.N. and YASUDA, Y. (2005b). Contamination of mercury in marine environment of Buyat Bay, North SulawesiIndonesia, and its potential impact to human. Proceedings of International Seminar on Mining, Environment, and Sustainability Development, 257-271.

LASUT, M.T., JENSEN, K.R., ARAI, T. and MIYAZAKI, N. (2005a) An assessment of water quality along the rivers loading to the Manado Bay, North Sulawesi, Indonesia. Coastal marine Science, 29(2), 124-132.

LASUT, M.T. 2009. Proses bioakumulasi dan biotransfer merkuri $(\mathrm{Hg})$ pada organisme perairan di dalam wadah terkontrol. JMS (Jurnal Matematika \& Sains), 14(3), 420-424.

LASUT, M.T., YASUDA, Y., EDINGER, E.N. and PANGEMANAN, J.M. (2010) Distribution and accumulation of mercury derived from gold mining in marine environment and its impact on residents of Buyat Bay, North Sulawesi, Indonesia. Water, Air, and Soil Pollution, 208, 153-164.

OUYANG, Y. (2012) Estimation of shallow groundwater discharge and nutrient load into a river. Ecological Engineering, 38, 101-104.

SUDARMADJI, MUKONO, J. and CORIE, I.P. (2006) Toksikologi logam berat B3 dan dampaknya terhadap kesehatan. Jurnal Kesehatan Lingkungan, 2(2), 129-142.

TRIYANI, A. (2009) Kandungan merkuri pada air dan akumulasinya pada daging ikan patik (Mystus micracanthus bleeker) di sungai sepauk Kalimantan Barat. Program Studi Biologi. Fakultas Teknobiologi. Yogyakarta: Universitas Atmajaya.

WHO (1990) Methylmercury. In Environmental Health Criteria 101. Geneva: World Health Organization.

IADC/CEDA (1997) Environmental aspects of dredging-conventions, codes and conditions: marine disposal. Netherlands: International Association of Dredging Companies (IADC) $\&$ Central Dredging Association (CEDA).

Received: 5 December 2018 Accepted: 2 February 2019 